\title{
How-To Optics
}

\author{
Sven Dupré \\ Utrecht University and University of Amsterdam, Email: S.G.M.Dupre@uu.nl
}

\section{Introduction}

'We shall speak of a fully perspectival view of space', Erwin Panofsky famously wrote in his Perspective as Symbolic Form, 'not when mere isolated objects, such as houses or furniture, are represented in foreshortening, but rather only when the entire picture has been transformed into a window, and when we are meant to believe we are looking through this window into a space'. ${ }^{1}$ Building on Alberti's conceptualization of painting as a window, for Panofsky, perspective entailed a new geometrical conception and depiction of space. However, several scholars have posited in more recent times that perspective as defined by Panofsky is a modern construct, and Panofsky's definition of perspective still haunts presentday scholarship on the history of perspective in the histories of science and art. ${ }^{2}$ Most recently, Hans Belting even revived Panofsky's notion of perspective as 'symbolic form' implying that it was 'expressive' of Renaissance culture. ${ }^{3}$ The deconstruction of Panofsky's definition of perspective first and foremost entails the recognition of the polysemy of optics: the plurality of cultures, practices and meanings of perspective.

The plurality and polysemy of Renaissance perspective plays out on three levels. First, contrary to Panofsky's elevation of Albertian perspective as the costruzione legittima, it has been shown, on the basis of the study of the material practices of painters in imitating and representing the effects of light and space, that Renaissance artists used several, sometimes incompatible techniques to create the illusion of three dimensions on a two-dimensional surface. ${ }^{4}$ Not only were there a variety of constructions to create the illusion of space, other types of optical knowledge and experience were as important to artists as the geometry of

\footnotetext{
${ }^{1}$ Erwin Panofsky, Perspective as Symbolic Form, trans. by Christopher S. Wood (New York: Zone Books, 1997), p. 27.

2 The most eloquent criticism of Panofsky's Perspective as Symbolic Form is perhaps James Elkins, The Poetics of Perspective (Ithaca: Cornell University Press, 1994).

${ }^{3}$ Hans Belting, Florence and Baghdad: Renaissance Art and Arab Science, trans. by Deborah Lucas Schneider (Cambridge, Mass.: Belknap Press of Harvard University Press, 2011).

${ }^{4}$ Pietro Roccasecca, 'Gentile da Fabriano, A Miracle of Saint Nicholas: A Rigorous Nonperspective Spatial Representation', Center: Record of Activities and Research Reports, National Gallery of Art, Washington, 21 (2001), 126-30; Pietro Roccasecca, 'Not Albertian', Center: Record of Activities and Research Reports, National Gallery of Art, Washington, 22 (2002), 167-69.
} 
perspective. $^{5}$ This recognition of the polysemy of perspective necessitates important corrections to David Lindberg's classic study of the history of optics from Antiquity to Johannes Kepler. ${ }^{6}$ Following Panofsky, the categories of perspectiva naturalis and perspectiva artificialis were projected back into the period of the Renaissance, driven by the desire to find a rupture between the Middle Ages and the Renaissance. While perspectiva naturalis or communis referred to the general category of the science of optics, including questions of psychology, physiology, anatomy, physics, and mathematics, perspectiva artificialis was the more limited domain of the geometrical technique (not the science) of drawing in perspective. This presentation of perspectiva naturalis and perspectiva artificialis as two different and largely independent enterprises had serious distorting consequences for Lindberg's presentation of the role of perspective in the history of optics. Lindberg discussed perspective as an impoverished 'application' of optical theory with no development of its own and very little consequence for the route taken by the discipline of optics. As we know, the distinction between optics and perspective fails to find support in the sources. All aspects of perspectiva, anatomical, physiological, physical, geometrical, psychological, were in fact inseparable, and authors, such as Lorenzo Ghiberti, Leonbattista Alberti and Piero della Francesca, considered themselves to be working on perspectiva just as much as their thirteenth-century predecessors.

The polysemy of perspective also plays out in a second way. Panofsky's definition ties perspective to the two-dimensional picture plane and as such attributes the development of perspective to one particular group of artisans, painters. However, several historians of architecture, urban planning and gardening (such as Marvin Trachtenberg and Georges Farhat) have argued that perspective was developed as much in real sites (such as the garden and the urban piazza) as on the two-dimensional picture plane. ${ }^{7}$ More generally, to do justice to the plurality and polysemy of Renaissance perspective, we need to treat the disciplinary histories of optics and perspective in terms of practices, a conglomerate of material, social, literary and reproductive practices, through which knowledge claims in optics were produced,

\footnotetext{
${ }^{5}$ Sven Dupré, 'The Historiography of Perspective and "Reflexy-Const" in Netherlandish Art', Nederlands Kunsthistorisch Jaarboek, 61 (2011), 35-60; Paul Hills, Venetian Colour: Marble, Mosaic, Painting and Glass 1250-1550 (New Haven: Yale University Press, 1999); and the contributions by Marjolijn Bol and Paul Hills in this volume.

${ }^{6}$ David C. Lindberg, Theories of Vision. From al-Kindi to Kepler (Chicago: University of Chicago Press, 1976). For a development of this argument, see Dupré, "The Historiography of Perspective and "Reflexy-Const", pp. 35-60; with reference to Dominique Raynaud, L'hypothèse d'Oxford. Essai sur les origins de la perspective (Paris: Presses universitaires de France, 1998).

${ }^{7}$ Marvin Trachtenberg, Dominion of the Eye: Urbanism, Art and Power in Early Modern Florence (Cambridge: Cambridge University Press, 1997); and the contributions by Marvin Trachtenberg and Georges Farhat in this volume.
} 
promoted, legitimated and circulated in and through a variety of sites and institutions. The ways optics were used by different groups in different places (such as the university classroom, the anatomist's dissection table, the goldsmith's workshop, and the astronomer's observatory) defined the meanings of Renaissance perspective. As this period was characterized by widespread 'optical literacy', perspective was defined in different ways in different places and sites by various groups of practitioners. ${ }^{8}$

\section{The Materiality of Perspective}

Finally, the polysemy of perspective plays out on a third level, one with which I am primarily concerned in this essay: the recognition of the materiality of perspective. There are two interconnected aspects to the materiality of perspective. First, I show how writing and reading practices in the Renaissance, that is, the materiality of texts on optics and perspective, contributed to artists' establishment as experts based on their knowledge of the secrets of perspective. Against the background of recent discussions of the artist as reader, artisanal literacy, and the role of reading, drawing and writing in Renaissance workshops, I will explore artists' readings and writings of optics. Most artist-readers, like other artisanal or vernacular readers, engaged with texts in a piecemeal fashion. Also, they were more likely to encounter optics cut and pasted as parts of recipe collections or books of secrets, which flooded the print market in the sixteenth century. Recipes and secrets were transforming vehicles for the transmission of optics. In this process of transformation, optical knowledge was separated from the context of the source text and the received conceptual apparatus of optics was left open for creative (re-)interpretations. As a consequence, readers of books of secrets and recipe collections gained a different image of perspective than that of more exceptional and scholarly readers engaging with 'complete' texts on optics.

Repackaged as secrets, optical knowledge served to establish a community of experts. ${ }^{9}$ This is also what Federico Cesi, founder of the Academy of the ('sharp-sighted') Lynceans, had in mind when he thanked Galileo for sending him a copy of Antonio Neri's treatise $L$, arte vetraria, the first published treatise on glassmaking. Cesi wrote that the book left him 'molto ricco d'esperienze e belli artificii' ('very rich in experiences and beautiful artifices'). ${ }^{10}$ Neri himself claimed to have been the first to reveal the 'hidden things' of this art to benefit

\footnotetext{
${ }^{8}$ For the term 'optical literacy', see A. Mark Smith, From Sight to Light: The Passage from Ancient to Modern Optics (Chicago: University of Chicago Press, 2014).

${ }^{9}$ Sven Dupré, 'Trading Luxury Glass, Picturing Collections and Consuming Objects of Knowledge in Early Seventeenth-Century Antwerp', Intellectual History Review, 20 (1) (2010), 53-78.

${ }^{10}$ Cited from Detlef Heikamp, Studien zur mediceischen Glaskunst: Archivalien, Entwurfszeichnungen, Gläser und Scherben (Florence: Kunsthistorisches Institut, 1986), p. 356.
} 
the 'experts of this profession'. ${ }^{11} \mathrm{He}$ emphasized that those who wish to try out his recipes need experience, practice, a good eye and judgment. ${ }^{12}$ The book thus served to establish a community based on shared maker's knowledge, much as envisioned by the re-packaging of optical knowledge as secrets. These secrets typically concerned visual distortions and optical illusions. Just like the pre-occupation with anamorphic images, which Stuart Clark opposed to Ivins' characterization of perspective as the 'rationalization of sight', the period's fascination with these secrets speak of the deep epistemological anxiety, widely felt in the long sixteenth century, over whether human vision could give reliable access to the real world at all. ${ }^{13}$

Following the work of William Eamon, in recent years it has been convincingly argued that the popularization of the tradition of secrets, peaking in the sixteenth century, laid the groundwork for the empirical culture found in seventeenth and eighteenth century scientific practice. ${ }^{14}$ Implicitly or explicitly, this work endorses the Kuhnian distinction between a mathematical and experimental tradition in early modern science, and associates sixteenth-century books of secrets primarily with the development of 'Baconian sciences' like chemistry, metallurgy, and magnetism.

This essay is a contribution to our understanding of the impact of books of secrets on the mathematical sciences. Scrutinizing optical secrets, it explores the still little understood shared 'experimentalism' in natural magic and mathematics. Dana Jalobeanu and Cesare Pastorino have recently argued that 'this new experimentalism permeated even traditionally bookish disciplines, such as natural history, which became, in the writings of Francis Bacon, experimental, collaborative and practically oriented'. ${ }^{15}$ They point to Bacon's posthumously published Sylva sylvarum (1626), which like Giambattista della Porta's Magia naturalis was a vast collection of miscellaneous experiments ranging from distillations to cross-breeding, and from the making of gold to 'talking heads'. In fact, Dan Garber has shown that quite a few of Bacon's experiments were taken from Della Porta's Magia naturalis, and placed in a different

\footnotetext{
${ }^{11}$ Antonio Neri, L'Arte vetraria distinta in libri sette (Florence: de' Gunti, 1612), Address to the 'curious reader'.

${ }^{12}$ Sven Dupré and Christine Göttler, 'Hidden Artifices', in Knowledge and Discernment in the Early Modern Arts, ed. by Sven Dupré and Christine Göttler (New York: Routledge, 2017), pp. 1-16.

${ }^{13}$ Stuart Clark, Vanities of the Eye: Vision in Early Modern European Culture (Oxford: Oxford University Press, 2007), 1-4.

${ }^{14}$ William Eamon, Science and the Secrets of Nature: Books of Secrets in Medieval and Early Modern Culture (Princeton: Princeton University Press, 1994); Secrets and Knowledge in Medicine and Science, 1500-1800 ed. by Elaine Leong and Alisha Rankin (Aldershot: Ashgate, 2011).

${ }^{15}$ Dana Jalobeanu and Cesare Pastorino, 'Introduction', in 'Instruments \& Arts of Inquiry: Natural History, Natural Magic and the Production of Knowledge in Early Modern Europe', Special Issue of Journal of Early Modern Studies, 3 (2014), 9-13 (p. 10).
} 
methodological and theoretical context. ${ }^{16}$ As I have argued elsewhere, in his ground-breaking work on optics, Johannes Kepler similarly used Della Porta's Magia naturalis as a source book of experiments. ${ }^{17}$ The re-packaging of optical knowledge as secrets consequentially shaped experiential knowledge in optics.

The second aspect to the materiality of perspective is that of the instruments of perspective. Precisely, the re-packaging of optical knowledge in secrets, underscored a definition of perspective as depending upon the bodily engagement with material objects and the manipulation of instruments. It is the materiality of the instruments of perspective which tends to be overlooked in Jonathan Crary's seminal Techniques of the Observer (1990). Convinced that a history of vision or perception 'depends on far more than an account of shifts in representational practices', Crary took as his problem, the observer. 'Vision and its effects are always inseparable from the possibilities of an observing subject who is both the historical product and the site of certain practices, techniques, institutions, and procedures of subjectification'. ${ }^{18}$

Crary's basic argument was that the early nineteenth century saw the creation of a new kind of observer. In the 1810 s and 1820s he located a rupture in the scopic regime between a geometric model of vision (in which vision was conceived as essentially passive and independent of the subject and based on a radical distinction between interior and exterior) and a physiological model of vision (in which vision became subjective, and the product of visual experience became located in the body of the observer). Crary developed his argument by contrasting two instruments, the camera obscura and the stereoscope, which he considered paradigmatic for his two models of vision respectively:

The optical devices in question, most significantly, are points of intersection where philosophical, scientific, and aesthetic discourses overlap with mechanical techniques, institutional requirements and socioeconomic forces. Each of them is understandable not simply as the material object in question, or as part of a history of technology, but for the way in which it is embedded in a much larger assemblage of events and powers. ${ }^{19}$

\footnotetext{
${ }^{16}$ Daniel Garber, 'Merchants of Light and Mystery Men: Bacon's Last Projects in Natural History', Journal of Early Modern Studies, 3 (1) (2014), 91-106.

${ }^{17}$ Sven Dupré, 'Kepler's Optics without Hypotheses', Synthese, 185 (2012), 501-25.

${ }^{18}$ Jonathan Crary, Techniques of the Observer: On Vision and Modernity in the Nineteenth Century (Cambridge, Mass.: The MIT Press, 1990), p. 5.

${ }^{19}$ Crary, Techniques of the Observer, 8.
} 
In this way, Crary kept far from any underlying assumption that artists used optical instruments to arrive at photographically realistic images, an underlying assumption developed by David Hockney's Secret Knowledge. ${ }^{20}$ Crary argues that

\begin{abstract}
many accounts of the camera obscura, particularly those dealing with the eighteenth century, tend to consider it exclusively in terms of its use by artists for copying, and as an aid in the making of paintings. There is often a presumption that artists were making do with an inadequate substitute for what they really wanted, and which would soon appear, that is, a photographic camera. ${ }^{21}$
\end{abstract}

While this deconstruction of the history of the camera obscura as a prelude to the photographic camera is what we gain from Crary's re-focusing on the history of the observer and techniques of observation, his account also falls into the trap of declaring the camera obscura paradigmatic, with all the consequent problems of such an approach already diagnosed in Bernhard Siegert's media history. ${ }^{22}$ Crary's sudden transposition of vision inside the body in the early nineteenth century and his very clear-cut division of the history of observation in a geometric and physiological scopic regime is one of the aspects that has repeatedly and justifiably come under attack by, among others, Erna Fiorentini in her work on the camera lucida. ${ }^{23}$ I will argue that the observer of the camera obscura is not passive, but instead constantly tinkering with the design of the camera obscura, and that observation with this instrument depends upon a bodily engagement rather than a strict division between the subject and the object, two aspects which Crary underestimated by de-materializing the camera obscura. ${ }^{24}$ In order to fully engage with this historiographical debate I will focus on instruments of perspective, including the camera obscura, mirrors and lenses. The tools of the draughtsman as well as the drawing techniques, occasionally codified as secrets or instructions, for example by Willem Goeree, deserve to be discussed if one adopts a focus on the materiality of perspective. However, they lie outside the scope of this chapter.

\title{
Lorenzo Ghiberti's Note-Taking in the Third Commentary
}

\footnotetext{
${ }^{20}$ David Hockney, Secret Knowledge: Rediscovering the Lost Techniques of the Old Masters (London: Thames \& Hudson, 2001); Sven Dupré, 'Optics, Instruments and Painting, 1420-1720: Reflections on the HockneyFalco Thesis', Special Issue of Early Science and Medicine, 10 (2) (2005), 125-339.

${ }^{21}$ Crary, Techniques of the Observer, 32.

${ }^{22}$ Bernhard Siegert, 'Kulturtechnik', in Einführung in die Kulturwissenschaft, ed. by Harun Maye and Leander Scholz (Munich: Wilhelm Fink Verlag, 2011), pp. 95-118.

${ }^{23}$ Erna Fiorentini, 'Subjective Objective. The Camera Lucida and Protomodern Observers', Bildwelten des Wissens: Kunsthistorisches Jahrbuch für Bildkritik, 2 (2004), 58-66.

${ }^{24}$ For perspective and the body, specifically in relation to anamorphic images, see also Lyle Massey, Picturing Space, Displacing Bodies: Anamorphosis in Early Modern Theories of Perspective (University Park, Pennsylvania: The Pennsylvania State University Press, 2007).
} 
Before I turn to the instruments of perspective, I focus on the materiality of texts on optics and perspective by scrutinizing the third commentary of Lorenzo Ghiberti. The writings of Ghiberti that have come down to us are given the title of I commentarii. They consist of three parts: one on ancient art, a second on modern art, and the third on vision and optics, our focus here. The nature of these writings is completely different from a treatise like, say, Alberti's De pictura. The third commentary is a compilation of excerpts from different authorities. Klaus Bergdolt has identified the source of most of these so that we now know that the most frequently excerpted sources are Pliny, Vitruvius' De architectura, and the works on perspectiva: the thirteenth-century optical works of Roger Bacon and John Pecham, and the work of the eleventh-century Ibn-Al Haytham, known in Latin as Alhacen, which Ghiberti studied in Italian translation. ${ }^{25}$ Although often dismissed in the literature as a thoroughly unoriginal compilation, the third commentary becomes of interest if considered as a product of Ghiberti's practice of reading and notetaking.

Recent studies have shown that there is a much stronger continuity between medieval and early modern writing and reading practices and between manuscript and print culture than previously thought. These studies lay to rest certain misconceptions perpetrated by earlier works on print culture (as found in Elizabeth Eisenstein's seminal work) such as, for example, that books produced prior to printing were inevitably riddled with errors. A radical transformation of written culture took place connected to the establishment of universities and new religious orders. New techniques and tools for rapid consultation, and use of an evergrowing body of texts associated with the proliferating curriculum of the universities emerged, and a new type of book was invented, containing such devices as running-titles, chapter headings, tables of contents and alphabetical indexes to cater for the needs of teachers and students. Even the long medieval tradition of observing the rational order of texts came under pressure as preachers, teachers and students broke up texts, copying bits and pieces to insert them into alphabetized compendia. These techniques of reading and writing foreshadow early modern methods of commonplacing which humanists and philosophers used in response to information overload. ${ }^{26}$ In the context of studies of artisanal literacy and the artist as reader, Heiko Damm, Michael Thimann and Claus Zittel have shown how artisans and architect-

\footnotetext{
${ }^{25}$ Klaus Bergdolt, Der dritte Kommentar Lorenzo Ghibertis: Naturwissenschaften und Medizin in der Kunsttheorie der Frührenaissance (Weinheim: VCH, Acta Humaniora, 1988). Also available on [Perspectiva+]: http://perspectiva.biblhertz.it/index.html [accessed 10-08-2017], including an Italian translation of Alhacen, Vat. Lat, 4595, Libro de li aspecti, transcribed by Pietro Roccasecca.

${ }^{26}$ Ann Blair, Too Much to Know: Managing Scholarly Information before the Modern Age (New Haven: Yale University Press, 2010).
} 
engineers adapted the humanist method of commonplacing to compile manuscripts of texts and drawings of a technical nature, carefully selected and copied. ${ }^{27}$

Ghiberti's third commentary is to be considered within this context of artists' adoption of humanist techniques of reading and notetaking. The study of Ghiberti's third commentary is then of interest for what it tells us about the artist's appropriation of optical knowledge. Ghiberti transformed the material from his sources to different degrees. Towards the beginning of the third commentary, in particular, Ghiberti's re-writing is particularly daring and he considerably expands upon his sources.

I discuss here only one telling example of such re-writing. In the early part of the third commentary Ghiberti discusses the nature of light. He selected passages from his sources, and then expanded on his reading by linking the notes to his workshop experiences as a goldsmith, jeweller and designer of stained glass windows. ${ }^{28}$ Immediately after distinguishing between three types of light or light-giving bodies (that is, light-giving, opaque and translucent or diaphanous bodies), a distinction, which Ghiberti took from the second book of Witelo's Perspectiva (as he indicated himself), he connected to examples he knew from his workshop practice:

The first is the sun and fire and some precious stones; the second [...] is that which is the earth or other hard or dark [tenebrosa] material. The third is the translucent [diafano] body: air, water, glass, crystal, chalcedony, beryl. ${ }^{29}$

The connection between the nature of light and precious stones was not new. The sources Ghiberti read had already established this connection. As Alhacen wrote:

Likewise, when transparent colored stones are in dark locations, their colors will appear dull and dark; but when intense light shines upon them, or when they are placed against a light-source so that its light shines through them, their colors will appear bright, and their transparency will be revealed by the passage of light [through them]. ${ }^{30}$

\footnotetext{
${ }^{27}$ Heiko Damm, Michael Thimann and Claus Zittel, The Artist as Reader: On Education and Non-Education of Early Modern Artists (Leiden: Brill, 2012).

${ }^{28}$ For Ghiberti's interest in glass and jewels, see Richard Krautheimer and Trude Krautheimer-Hess, Lorenzo Ghiberti (Princeton: Princeton University Press, 1982).

${ }^{29}$ Cited from John Gage, Colour and Meaning: Art, Science and Symbolism (London: Thames \& Hudson, 1999), p. 99.

${ }^{30}$ Alhacen, Alhacen's Theory of Visual Perception: A Critical Edition, with English Translation and Commentary, of the First Three Books of Alhacen's 'De aspectibus', the Medieval Latin Version of Ibn alHaytham's 'Kitāb al-Manāzir', ed. and trans. by A. Mark Smith, 2 vols (Philadelphia: Transactions of the American Philosophical Society, 2001), II, p. 347.
} 
Nevertheless, Ghiberti further expands on these notions and connections by referring to his own observations of the effects of the intensity of light on a gemstone he, as an expert, was allowed to study in a Florentine collection:

\begin{abstract}
Among the [most] remarkable things I ever saw is a wonderful engraved chalcedony which was in the collection of one of our citizens, by the name of Niccolo Landi, a very energetic researcher and investigator of many and excellent antiquities in our time, and into books of Greek and Latin writings. And among his other antiques he had this chalcedony [...] It was oval in shape, and on it was the figure of a youth holding a knife [The Rape of the Palladium]. [...] This carving was said by every expert in sculpture and painting, without exception, to be a marvellous thing [...] You could not see it well in a strong light, because when fine and polished stones are deeply cut, the strong light reflections obscure the understanding of the form. This carving could be seen best when the deeply-cut part was held against the strong light, when it could be seen perfectly. ${ }^{31}$
\end{abstract}

Formally, Ghiberti's excerpts differ from other writings connected to the art of jewellery and glassmaking, such as a manuscript on the making of stained glass windows, compiled in the late fourteenth century, by Antonio da Pisa. ${ }^{32}$ Antonio da Pisa's workshop was one of the most active in Florence and was involved in the making of stained glass windows for the cathedral. The book of Antonio da Pisa consists of a collection of recipes related to his art. The recipes contain knowledge of a different type than that excerpted by Ghiberti. I take one example from Antonio da Pisa. 'To make the yellow colour more intense', he advised the reader, 'to add a bit of ochre such as the painters use. But not too much because then the glass will look red'. ${ }^{33}$ Compare this to the passage in which Ghiberti refers to stained glass windows:

[...] when the sun's ray passes through a glass [window] or through a strongly coloured [oiled] cloth, the image of the colour appears upon the dark body [opposite]. ${ }^{34}$

In the third commentary, this passage follows a discussion of the nature of light and species or the forms or images, which each object sends through the medium. Ghiberti excerpted this note from Roger Bacon's discussion of the multiplication of species in his Perspectiva, one of

\footnotetext{
${ }^{31}$ Cited from Gage, Colour and Meaning, 100.

${ }^{32}$ Claudine Lautier and Dany Sandron, Antoine de Pise: L'art du vitrail vers 1400 (Paris, Comité des Travaux Historiques et Scientifiques, 2008).

33 ' $\mathrm{Si}$ più pieno de colore volessi fare quello callo, mictine dentro um pocho de ocrea, la quale adoperano I depentori e sit u glini mittissi troppo, ritornaria el vetro rosso, ma non seria bello colore che parria uno imbratto'. Lautier and Sandron, Antoine de Pise, 56.

${ }^{34}$ Cited from Gage, Colour and Meaning, 102.
} 
the key concepts of optics. ${ }^{35}$ Compared to Antonio da Pisa's recipes, Ghiberti's commentary shows that he read optical source texts and that he appropriated optical knowledge, also of a type not found in Antonio da Pisa, for example, when Ghiberti speaks of the nature of light. Nevertheless, Ghiberti's reading is selective when excerpting and re-ordering materials from his sources. While his reading established his expertise, the theoretical framework of vision is partly lost.

\section{Writing Optics: Recipes and Secrets}

Artist-readers such as Ghiberti who engaged with 'complete' texts were exceptional. Most artist-readers, like other artisanal or vernacular readers, engaged with texts in a piece-meal fashion. They were more likely to encounter optics cut and pasted as part of collections of recipes and books of secrets. In this second part of my essay I turn to recipe collections, such as Antonio da Pisa's, with which I have compared Ghiberti's third commentary. Although there are few traces of artists' marginal annotations to collections of recipes and books of secrets to give us direct insight into their reading practices, we do have access to the collections of recipes and books of secrets themselves which artists were primarily confronted with and thus to the transformations of optical knowledge in the process of re-writing optical texts as recipes and secrets.

Recipes are probably as old as mankind's writing ability. We have clay tablets inscribed with Babylonian glass recipes, and the so-called Leiden and Stockholm Papyri contain recipes for several arts and crafts and have a long after-history reaching the early modern period. ${ }^{36}$ By this time recipes were ubiquitous. Recipes that appeared in print in sixteenth-century books of secrets often had a pre-history in manuscript collections of recipes. Manuscript and print were and remained co-existent traditions. One point to make about these recipes and secrets is their longevity.

Avidly collected in manuscript notebooks and publicised in books of secrets flooding the print market, these recipes instructed readers how to colour glass, make gold, and brew medicine. A good part of the late medieval and early modern recipes that have come down to us concern medicine and the visual and decorative arts. In the latter category, Cennino Cennini's Libro del' arte is one of the more well-known collections, the fame of which is

\footnotetext{
${ }^{35}$ Roger Bacon, Roger Bacon's Philosophy of Nature: A Critical Edition, with English Translation, Introduction, and Notes, of 'De multiplicatione specierum' and 'De speculis comburentibus', ed. and trans. by David C. Lindberg (Oxford: Clarendon Press, 1983).

${ }^{36}$ For the Leiden and Stockholm Papyri, see Lawrence Principe, The Secrets of Alchemy (Chicago: University of Chicago Press, 2013), pp. 10-13; Sven Dupré, Bert de Munck and Mark Clarke, Transmission of Artists '

Knowledge (Brussels: Royal Flemish Academy of Arts and Sciences, 2012).
} 
probably matched only by the recipes and workshop secrets which the physician Theodore de Mayerne compiled on the basis of conversations with Rubens, Van Dyck and their like. ${ }^{37}$

However, these collections are exceptions. These famous examples, connected with the name of their author or compiler, are only the tip of the iceberg. Hundreds of mostly anonymous collections of, taken all together, thousands of recipes hide beneath the water's surface. The more famous examples, like Cennini's, are also exceptional in the sense that they focus on one topic. A second point to make is that the most typical collections of recipes were miscellaneous in nature. Miscellaneous recipes also ended up in the libraries of artists. For example, Christine Sauer has identified such a manuscript, at one point, as being in the hands of Albrecht Dürer. ${ }^{38}$ This fits the more general picture of the evolution of artisanal literacy in the early modern period; more and more artisans were able to read and write, and they increasingly possessed books and home libraries, and the number of books they possessed also increased. ${ }^{39}$ The early modern period saw a transition in which artisans claimed authorship of knowledge specific to their craft and in which artisans also began to partly learn their trade through writings.

One of the best-known examples of a book of secrets is Giovanni Battista della Porta's Magia naturalis, published in 1558, and in an expanded version in 1589. Here, amidst secrets of all kinds of other productive knowledge, we find optical secrets revealing, for example, how to make a burning mirror or how to project an image in the air. This secret is also found in collections of recipes prior and contemporaneous to Della Porta's book of secrets. For example, the mid-sixteenth-century manuscript collection of recipes, brought together by the Antwerp apothecary Peter Van Coudenberghe, is very similar in content and organization to books of secrets published in the same period. ${ }^{40}$ Partly written in Latin, and partly in Dutch, the recipes in Latin are diverse in nature (dealing with cooking, medicine, alchemy, and the

\footnotetext{
${ }^{37}$ Lara Broecke, Cennino Cennini's Il libro dell'arte: A New English Translation and Commentary with Italian Transcription (London: Archetype Publications, 2015). For Mayerne and his manuscript, see H. Trevor-Roper, Europe's Physician. The Various Life of Sir Theodore de Mayerne (New Haven: Yale University Press, 2006); Ulrike Kern, 'The Art of Conservation I: Theodore de Mayerne, the King's Black Paintings and SeventeenthCentury Methods of Restoring and Conserving Paintings', The Burlington Magazine, 157 (2015), 700-708. ${ }^{38}$ Christine Sauer, 'Eine kunsttechnologische Handschrift aus dem Besitz Albrecht Dürers', in DürerForschungen (Nürnberg: Verlag des Germanischen Nationalmuseums, 2009), II, pp. 275-96.

${ }^{39}$ Michael Hackenberg, 'Books in Artisan Homes of Sixteenth-Century Germany', Journal of Library History, 21 (1986), 72-91; Bert S. Hall, 'Der Meister sol auch Kennen Schreiben und Lesen: Writings about Technology ca. 1400-ca. 1600 A.D. and their Cultural Implications', in Early Technologies, ed. by Denise SchmandtBesserat (Malibu: Undena Publications, 1979), pp. 47-58; Pamela O. Long, Openness, Secrecy, Authorship: Technical Arts and the Culture of Knowledge from Antiquity to the Renaissance (Baltimore: Johns Hopkins University Press, 2001).

${ }^{40}$ Sven Dupré, 'The Value of Glass and the Translation of Artisanal Knowledge in Early Modern Antwerp', in Trading Values in Early Modern Antwerp, ed. by Bart Ramakers, Christine Göttler, and Joanna Woodall, Netherlands Yearbook for Art History, 64 (Leiden: Brill, 2014), pp. 138-61; E. Vandamme, 'Een 16e-eeuws Zuidnederlands receptenboek', Jaarboek van het Koninklijk Museum voor Schone Kunsten (1974), 101-37.
} 
making of glass and colours), while the longer Dutch part contains recipes which are mostly of art's technological origin: the making of colours in different media, inks, glassmaking, and in this section also, optical secrets, that is, recipes for the construction of mirrors. ${ }^{41}$ Recipe collections were vehicles for optical knowledge.

This is most tellingly the case for the circulating copies of the Secretum philosophorum. ${ }^{42}$ It was originally composed in England in the late thirteenth or early fourteenth century. Devoted to the seven liberal arts, it was nevertheless more than just another university textbook. The first section on grammar consisted of recipes explaining how to construct a pen and how to make inks, and the third section, on dialectic, listed secrets on how to deceive the senses, including some on how to deceive the sense of sight. More strongly organized (according to the scheme of the liberal arts) than most recipe collections, it is nevertheless typically miscellaneous.

I want to make four points about books of secrets on the basis of the example of the Secretum philosophorum. The first is about ambiguity of meaning. This is one secret 'to make a mirror in which many moving images will appear in a single place':

\begin{abstract}
You can also make a mirror in which, in one glance, many moving images will appear, and this is how it is done. Take a very deep box and place in the bottom of it an ordinary mirror - that is, a convex one. Next, take six or seven other convex mirrors of the same size, and scrape off with a knife their lead which is on the concave side. But you should know that it is very difficult to scrape off all the lead cleanly, without breaking the glass. So if you want to clean the mirrors well and remove the lead, take some quicksilver and rub the lead with it, and straight away it will adhere to the lead and penetrate it, so that after a little time you can easily remove the lead completely from the mirror. Now, when they are very clean, put them in the box, but in such a way that they stand aslant on the mirror and, moreover, in different positions, which you will do thus. When the first mirror has been placed in the bottom, you will place the second mirror so that one side is attached to the first mirror and the opposite side is distant from it by one finger; and, in this way, you will put the other mirrors in the box, but in different positions. But on the top surface of the box you will put a mirror (which has been cleaned as above) straight and not aslant and then adjust them well so that only the topmost mirror is seen. Then if you look in the mirror, you will see as many images as there are mirrors. But if you turn the mirror, you will
\end{abstract}

\footnotetext{
${ }^{41}$ For example, Om brant spiegels te ghieten ('To cast burning mirrors'), in: Vandamme, 'Een 16e-eeuws Zuidnederlands receptenboek', 101-37 (p. 121).

${ }^{42}$ Robert Goulding, 'Deceiving the Senses in the Thirteenth Century: Trickery and Illusion in the Secretum philosophorum', in Magic and the Classical Tradition, ed. by C. Burnett and W. F. Ryan (London: The Warburg Institute, 2006), pp. 135-62. See also Mark Clarke, 'Writing Recipes for Non-Specialists, c. 1300: The AngloLatin "Secretum philosophorum", Glasgow MS Hunterian 110', in Sources and Serendipity: Testimonies of Artists' Practice, ed. by Erma Hermens and Joyce H. Townsend (London: Archetype Publications, 2009), pp. $50-64$.
} 
see how one image always stays in the middle and in one position and the other images come to meet it as if they were doing a dance. ${ }^{43}$

The secret describes two different processes: how to make glass mirrors (starting from the then more common convex mirrors), and how to assemble the mirrors in such a way, specifying distances and positions of the respective mirrors, as to create a particular optical effect (dancing images). Depending upon our interpretation of positions and distances, there seems to be more than one way to put together this optical instrument. While it is possible to reconstruct an optical object by following this text, as I have attempted in collaboration with Carsten Wirth (Figure 1), ambiguity of meaning is nevertheless the rule in books of secrets. This ambiguity is enhanced by the typical absence of diagrams or drawings of instrument designs. $^{44}$

A second point I want to make is about transmission. Not only did secrets travel as part of the Secretum philosophorum, they also travelled independently. In this process of transmission, the secrets were re-organized and appeared in different contexts. For example, Jean Fusoris was an early fifteenth-century mathematician and instrument maker, based in Paris. ${ }^{45} \mathrm{He}$ also showed interest in optics, in particular, in burning mirrors, and more generally, as his annotations to Witelo's Perspectiva and other notes show, catoptrics and image formation. His manuscript on burning mirrors (a variation on the Libellus almukesi compositio), now in the Bibliotheque municipale in Dijon, also contains a note on 'speculum in quo visu uno multe apparebunt ymagines se moventes constituere' ('how to make a mirror in which many moving images of one object appear'), which is taken from the Secretum philosophorum. ${ }^{46}$ In short, optical secrets from the Secretum philosophorum travelled independently and were combined with, for example, a treatise on burning mirrors.

\section{The Manipulation of Optical Objects}

\footnotetext{
${ }^{43}$ Goulding, 'Deceiving the Senses in the Thirteenth Century', pp. 135-62 (esp. pp. 155-56).

${ }^{44}$ On the (absence of) imagery in how-to texts, see also Sven Dupré, 'Die Sichtbarkeit und Unsichtbarkeit von Körperwissen in der Kodifikation der Künste in der frühen Neuzeit', Paragrana: Internationale Zeitschrift für Historische Anthropologie, 25 (1) (2016), 110-29.

${ }^{45}$ Emmanuel Poulle, Un constructeur d'instruments astronomiques au XVe siècle: Jean Fusoris (Paris: Librairie Honoré Champion, 1963).

${ }^{46}$ Bibliothèque municipale, Dijon, 441 (226), fol. $206^{\mathrm{r}}$. The complete passage is transcribed in Grażyna Rosińska, 'Optyka W XV wieku miedzy nauka sredniowieczna a nowozytna' ('Fifteenth Century Optics between Medieval and Modern Science'), Studia Copernicana, 24 (1986), 151. For the corresponding, almost identical, passage in an English manuscript, see British Library, London, Egerton 2852, fol. 19 ${ }^{\mathrm{r}}$ (transcribed in Rosińska, 'Optyka W XV wieku', p. 168).
} 
A third point: the secrets re-packaged optical knowledge aiming to create visual effects through the manipulation of objects or instruments. In the Secretum philosophorum these are mirrors (turned into glass spheres) and the visual effect depends upon the bodily engagement with the material objects. Only when the eye is positioned at a particular point of view with respect to the glass spheres, are the visual effects described in the secrets created. This is different from Crary's imagination of the camera obscura experience to which this secret is related. The emphasis on bodily engagement becomes clear in early modern descriptions of the camera obscura, such as the one by Johannes Kepler, one of the most important mathematicians and astronomers of the seventeenth century, whose book Paralipomena, published in 1604, laid the foundations of our modern theory of vision based on the analogy between the eye and the camera obscura. In this book, Johannes Kepler mentioned

[...] an experimentum [...] which I saw at Dresden in the elector's theater of artifices [...] A disk thicker in the middle, or a crystalline lens, a foot in diameter, was standing at the entrance of a closed chamber against a little window, which was the only thing that was open, slanted a little to the right. Thus when the eyesight travelled through the dark emptiness, it also, fortuitously, hit upon the place of the image, nearer, in fact, than the lens. And so since the lens was weakly illuminated, it did not particularly attract the eyes. But the walls were also not particularly conspicuous through the lens, because they were in deep darkness. ${ }^{47}$

The setting was the Dresden Kunstkammer, a place of display in which collected natural objects were juxtaposed with artificial objects, typically found at Renaissance courts. ${ }^{48}$ In one of the rooms of the Dresden Kunstkammer, which had been turned into a room-size camera obscura, Kepler witnessed the images formed by a lens placed in the aperture of this camera obscura, which, in fact, was one of the little windows of the Kunstkammer room through which light from outside was able to enter. In this darkened room Kepler saw that 'the little window and the objects standing about it, which had the benefit of much light, lying hidden

\footnotetext{
47 ، $[. .$.$] cuius experimentum vidi Dresdae in Theatro artificiali Electoris. [...] Discus in medio crassior, seu lens$ crystallina, pedis diametro, stabat in ingressu camerae clausae contra fenestellam, quae unica patebat, declinantem parùm ad dextram. Dum igitur oculorum acies tenebrosam capacitatem pererrant, fortuitò, et in locum imaginis incidunt, propiorem quidem quàm erat lens. Cum itaque lens malignè illustraretur, oculos non admodum erant conspicui; quia in multis tenebris'. Johannes Kepler, Gesammelte Werke, ed. by Max Caspar and Walter van Dyck, 23 vols (Munich: C. H. Beck, 1938), II, pp. 164-65. Translation in Johannes Kepler, Optics. Paralipomena to Witelo and \& Optical Part of Astronomy, trans. by William H. Donahue (Santa Fe: Green Lion Press, 2000), p. 194.

${ }^{48}$ Sven Dupré and Michael Korey, 'Inside the Kunstkammer: The Circulation of Optical Knowledge and Instruments at the Dresden Court', Studies in History and Philosophy of Science, 40 (4) (2009), 405-20.
} 
beyond the lens, set up a bright image of themselves in the air (between me and the lens)' ${ }^{49}$

If we think of the camera obscura today, the object that comes readily to mind is a sort of box-type camera obscura, at least something that is fixed in terms of object and optical design, perhaps even portable. As one can clearly see from the example of Kepler's description of his camera obscura experience in Dresden, this was not the case in the early seventeenth century. The camera obscura was a darkened room, and the optics were brought and installed for the specific purpose. In Dresden a crystal ball, a gift presented to the Elector of Saxony, August I, by the Duke of Savoy in 1580 and prominently displayed in the most important room of the Dresden Kunstkammer, was occasionally moved to a dark room in the Kunstkammer to project images. ${ }^{50}$

This underscores the process and event character of the camera obscura experience. It also means that there was no standardized and stabilized optical design of dark room experiences. Instead, various and different optical design elements (lenses, mirrors, apertures) were brought together and assembled in diverse ways resulting in various image appearances. Nevertheless, by the seventeenth century, attempts were being made to make the camera obscura portable so that it could be used out in the field to draw landscapes. However, the 'picture box' developed by Robert Hooke, the curator of experiments at London's Royal Society, shows how difficult it must have been to create a darkened room on a smaller scale. ${ }^{51}$ (Figure 2) How would Hooke's draughtsman have kept his balance with this picture box on his head? More than just a model of vision, the failures and successes of making the camera obscura portable highlight the practical difficulties of using the camera obscura as a drawing instrument. Rather than a model of passive, objective vision, as Crary would have wanted it, Hooke's 'picture box' was an extension of the draughtsman's body.

The ways in which optical knowledge is packaged in Secretum philosophorum is similar to that in the Kunstbüchlein, following in the footsteps of Dürer's Underweysung der Messung. ${ }^{52}$ Messung was used interchangeably, as a translation of perspectiva, and it entailed a particular definition of perspective. Dürer used Messung to refer to constructive geometry (by ruler and compass) with an emphasis on three-dimensionality and materiality, that is on

\footnotetext{
49 'At fenestella et circumstantes res, quae multa luce fruebantur, post lentem latentes, claram sistebant in aëre (me inter et lentem) sui imaginem'. Kepler, Gesammelte Werke, ed. by Caspar and Van Dyck, II, p. 165. Translation in Johannes Kepler, Optics, trans. by Donahue, p. 194.

${ }^{50}$ Dupré and Korey, 'Inside the Kunstkammer', pp. 405-20.

${ }^{51}$ For the portable camera obscura, see Joachim Rees, Die verzeichnete Fremde: Formen und Funktionen des Zeichnens im Kontext europäischer Forschungsreisen 1770-1830 (Paderborn: Wilhelm Fink, 2015), pp. 275326.

52 Jeanne Peiffer, 'Projections Embodied in Technical Drawings: Dürer and his Followers', in Picturing Machines 1400-1700, ed. by Wolfgang Lefèvre, (Cambridge, Mass.: The MIT Press, 2004), pp. 245-75.
} 
drawing artefacts placed before artists, in contrast to demonstrative geometry. Dürer's Underweysung der Messung is not to supply his readers with a geometrical explanation of why a construction works, but to teach them how to perform the construction. In Dürer's Underweysung der Messung there is an emphasis on instruments for drawing in perspective. However, while Dürer's instruments are more pedagogical embodiments of Alberti's perspective, later German sixteenth-century writers on Messung emphasized the constructive use of instruments to create non-Albertian perspective. Messung was thus a particular embodiment of perspective, explicitly defined as based on the manipulation of instruments. It was a re-definition of perspective also pervading books of secrets.

\section{How-To Optics}

A fourth and final point: secrets packaged optical knowledge as 'how-to' guides. This engaged the reader in trying and testing the experiments. While inviting testing, recipes and secrets should not be considered experiments. More often they are the products of reading experiences, copied and pasted from other sources. For example, Della Porta's secret of how to draw a parabolic section (given the focal distance), and how to make a parabolic burning mirror, is taken from Oronce Finé's De speculo ustorio, a book bringing together technical and mathematical knowledge of mirrors. ${ }^{53}$ Della Porta probably knew this book through its publication in 1587 as an appendix to Cosimo Bartoli's translation of Fine's Protomathesis, in an Italian translation by Ercole Bottrigaro, a Bolognese humanist who had also edited Ptolemy's Geographia. Della Porta's secret was taken, almost verbatim, from Finé's Propositions 8 and 9. In fact, it has been shown that Della Porta borrowed the diagrams of $D e$ speculo ustorio as well as Finé's mistakes. ${ }^{54}$

However, although Della Porta's secret is taken from a textual source, this appropriation took place in a context of making. Della Porta collaborated on the construction of a parabolic burning mirror with Jacomo Contarini, the Provveditore of the Arsenal in Venice and a collector of books, manuscripts and instruments. ${ }^{55}$ In 1580, Della Porta's patron, the Cardinal d' Este, sent him to Venice to make or obtain a parabolic burning mirror. Looking for guidance to construct a parabolic burning mirror, he turned to Jacomo Contarini,

\footnotetext{
${ }^{53}$ Sven Dupré, 'Printing Practical Mathematics: Oronce Fine's "De speculo ustorio" between Paper and Craft', in The Worlds of Oronce Finé: Mathematics, Instruments and Print in Renaissance France, ed. by Alexander Marr (Donington: Shaun Tyas, 2009), pp. 64-82.

${ }^{54}$ Marshall Clagett, Archimedes in the Middle Ages. Vol. 4: A Supplement on the Medieval Latin Traditions of Conic Sections (Philadelphia: The American Philosophical Society, 1980), p. 331.

${ }_{55}$ Paul Lawrence Rose, 'Jacomo Contarini (1536-1595), a Venetian Patron and Collector of Mathematical Instruments and Books', Physis, 18 (2) (1976), 117-30.
} 
presumably not only to provide the means, but also the skills. On 29 November 1580, Della Porta wrote to his patron that Contarini had spent a day and most of a night at the Arsenal with him supervising an attempt by one of the Arsenal craftsmen to cast a parabolic mirror. It was through Contarini that Della Porta encountered Oronce Finé's work on burning mirrors.

It is through this same network that Della Porta also came across the work of the Venetian mathematician Ettore Ausonio. When Della Porta visited Venice in 1580 to attend the construction of a parabolic mirror, he also met Paolo Sarpi, who may already have been aware of Ausonio's Theorica speculi concavi sphaerici, which he later copied himself. ${ }^{56}$ What follows are a few examples of Della Porta's optical secrets which likely had their source in his reading of Ausonio. First, Della Porta's secret of how, using a plane mirror, 'letters may be cast out and read, on a wall that is far distant':

On the superficies of a plain Glass, make Letters with black ink, or with wax, that they may be solid to hinder the light of the Glass, and shadow it; then hold the Glass against the Sun-beams, so that the beams reflecting on the Glass, may be cast upon the opposite wall of a Chamber, it is no doubt but the light and letters will be seen in the Chamber. ${ }^{57}$

Ausonio's Theorica already proposed to project letters on a distant wall by means of a mirror and solar light. Second, Ausonio's secret of how to use candle light to read letters in an otherwise dark room was taken up by Della Porta who specified that it should be done by placing a candle in the focal point of the mirror:

Take the Glass in your hand, and set a candle to the point of Inversion, for the parallel beams will be reflected to the place desired, and the place will be enlightened above sixty paces, and whatsoever falls between the parallels, will be clearly seen: the reason is, because the beams from the Centre to the circumference, are reflected parallel, when the parallels come to a point; and in the place thus illuminated, letters may be read, and all things done conveniently, that require great light. ${ }^{58}$

Third, Della Porta's secret of how to kindle fire:

\footnotetext{
${ }^{56}$ Sven Dupré, 'Mathematical Instruments and the "Theory of the Concave Spherical Mirror": Galileo's Optics beyond Art and Science', Nuncius, 15 (2) (2000), 551-88.

${ }^{57}$ Giambattista della Porta, Natural Magick by John Baptista Porta, a Neapolitane: in Twenty Books ... Wherein are Set Forth all the Riches and Delights of the Natural Sciences (London: Printed for Thomas Young and Samuel Speed, 1658), p. 356.

${ }^{58}$ Porta, Natural Magick, 362.
} 
In a Concave spherical Glass the beams meeting together, kindle fire in a fourth part of the diameter under the Centre, which are directed within the side of a Hexagon from the superficies of the circle. ${ }^{59}$

This secret, too, and especially, the locus of the focal point of a concave spherical mirror at the fourth part of the diameter of the mirror, is taken from Ausonio.

A fourth example of appropriation concerns the secret of images in the air. In Chapter 10 Della Porta taught how 'to see an image hanging in the air' with a convex lens:

If you put the thing to be seen behind the Lenticular, that it may pass thorow the Centre, and set your eyes in the opposite part, you shall see the Image between the Glass and your eyes; and if you set a paper against it, you shall see it clearly: so that a lighted Candle will seem to burn upon the Paper. ${ }^{60}$

In Chapter 13 he told of how to make an image appear in the air with a crystal ball:

It will shew the Image in the Air, both before and behind. Let the Object be behind the Pillar, let the Pillar be between that and the eye, the Image will appear outwardly haging in the Air, above the Pillar, parted every where from the Pillar, clearly and perspicuously ${ }^{61}$

Della Porta's secrets are variations on a secret of how to make a mirror to make an image float in the air, already found in the Secretum Philosophorum:

\begin{abstract}
You can also make a mirror out of a convex mirror in which an image will appear outside, and this is how it is done. Take an ordinary mirror (that is, a convex one) and scrape off the lead and put it in a box, which is not too deep, so that the convexity is towards the bottom of the box, and the concavity is outwards. Then put something dark between the bottom of the box and the mirror, such as the black cloth or some such thing, and do this so that the visual ray is better reflected. Then if you attentively gaze in the mirror, you will see your image outside the box, in the air between you and the mirror. ${ }^{62}$
\end{abstract}

The secret has its source in Witelo's Perspectiva, but travelled widely and independently, also outside the context of the Secretum philosophorum, in the fifteenth and sixteenth centuries. ${ }^{63}$ In fact, the ambiguous concept of 'image in the air' is a good example of a notion which

\footnotetext{
${ }^{59}$ Porta, Natural Magick, 370.

${ }^{60}$ Porta, Natural Magick, 368-69.

${ }^{61}$ Porta, Natural Magick, 370.

${ }^{62}$ Goulding, 'Deceiving the Senses in the Thirteenth Century', pp. 135-62 (esp. p. 156).

${ }^{63}$ For its source in Witelo, see A. Mark Smith, 'Reflections on the Hockney-Falco Thesis: Optical Theory and Artistic Practice in the Fifteenth and Sixteenth Centuries', Early Science and Medicine, 10 (2) (2005), 163-86.
} 
gained a life of its own without the constraints imposed by Witelo's Perspectiva and other perspectivist texts. ${ }^{64}$ This ambiguity and flexibility of meaning is a consequence of the separation of the secret from the context of the source text on optics following the process of copying, breaking up and re-writing more 'rationally ordered' optical source texts as standalone secrets. In sixteenth-century books of secrets the context which constrained the meaning of concepts and terms disappeared, leaving the reader with a wider field of interpretation, and also room for creative misunderstandings.

\section{Conclusion}

What happened to the meaning of perspective during the process of re-packaging optical knowledge as secrets? While artisans wrote down how to go about creating their works, they were also aware of the limits of their abilities to fix their knowledge in words. It is to characterize this unspeakable property of artisanal knowledge that Dürer evoked the term Augenmaß. In the Ästhetische Exkurs, Dürer wrote:

But if you have learned how to measure well, and added reason to practice so that you can make a thing with free assuredness, and know how to do justice to you're a thing, then it is not necessary to measure it all the time, for your accomplished art endows you with a good eye measure and your practiced hand obeys. $^{65}$

Related to period notions of ingenio or ingenium ('ingenuity') as innate talent or natural ability without instruction, Dürer's Augenmaß was Wissen ('knowledge') partly acquired through practice. Augenmaß guided the hand of the skilled artisan and allowed him to avoid yrthumb ('error') and falscheit ('falseness'). Following Dürer, numerous writers on the arts used the idea of Augenma $\beta$ to express that essential aspects of the making of art were a matter impossible to fix in words.

Dürer's Augenma $\beta$ is closely related to the visual 'discernment' and 'judgment by the eye' evoked by Neri, mentioned at the beginning of my essay. ${ }^{66}$ Neri conceptualized what the discerning eye saw as 'hidden', and thus as a 'secret' which was known only to the expert

\footnotetext{
${ }^{64}$ Sven Dupré, 'Images in the Air: Optical Games, Magic, and Imagination', in Spirits Unseen: The Representation of Subtle Bodies in Early Modern European Culture, ed. by Christine Göttler and Wolfgang Neuber (Leiden: Brill, 2008), pp. 71-92.

65 'Aber so du wol messen hast gelernt, und den verstandt mit sambt dem brauch uber kumen, also das du ein ding auß freyer gwißheyt kanst machen und weyst einem yetlichen ding recht zu thon, als dann ist nit alweg not, ein ydlich ding alweg zu messen, dan dein uberkumne kunst macht dir ein guten augen maß, als dann ist die geübt hand gehorsam'. Albrecht Dürer, Schriftlicher Nachlass, ed. by Hans Rupprich, 3 vols (Berlin: Deutscher Verlag für Kunstwissenschaft, 1969), III, p. 297.

${ }^{66}$ Dupré and Göttler, 'Hidden Artifices', pp. 1-16.
} 
artist. As I have argued in this essay, the collections of recipes artists were primarily confronted with in their search for optical knowledge packaged optical knowledge as 'secrets'. This entailed a re-definition of perspective. First, breaking-up optical source texts in this way solicited a process of translation and appropriation of optical knowledge. Secrets repackaged optical knowledge into 'how-to' chunks, thereby separating these chunks of optical knowledge for the creation of visual effects from the context of the source text. This allowed optical knowledge to travel more easily and enabled it to reach larger audiences of readers in the sixteenth century than ever before. Given the structure of books of secrets, these readers were also invited to try and test the optical recipes, and they did; the reader's experience was not always disassociated from the worlds of making and doing. However, the structure of books of secrets also created conceptual ambiguity, because in this process the theories of light and vision disappeared into the background. Second, the emphasis of the secrets was on the manipulation of objects and instruments to create particular optical effects. In contrast to Panofsky, and acknowledging the polysemy of perspective, the materiality of the texts on optics and perspective I have discussed constructed a particular definition of perspective similar to Dürer's Messung. The materiality of the objects and the instruments used to draw them in perspective were crucial to this definition of perspective. In contrast to Crary's geometric scopic regime, rather than making the draughtsman into a passive observer, these instruments, including the camera obscura, relied on the bodily engagement of the observer and the artist to create visual effects and to construct perspective. 


\section{Bibliography}

\section{Manuscript and Archival Sources}

Alhacen, Vat. Lat, 4595, Libro de li aspecti, transcribed by Pietro Roccasecca: [Perspectiva+]: http://perspectiva.biblhertz.it/index.html.

Bibliothèque municipale, Dijon, 441 (226), fol. 206 .

British Library, London, Egerton 2852, fol. 19

\section{Primary Sources}

Alhacen, Alhacen's Theory of Visual Perception: A Critical Edition, with English Translation and Commentary, of the First Three Books of Alhacen's 'De aspectibus', the Medieval Latin Version of Ibn al-Haytham's 'Kitāb al-Manāzir', ed. and trans. by A. Mark Smith, 2 vols (Philadelphia:

Transactions of the American Philosophical Society, 2001).

Bacon, Roger, Roger Bacon's Philosophy of Nature: A Critical Edition, with English Translation, Introduction, and Notes, of 'De multiplicatione specierum' and 'De speculis comburentibus', ed. and trans. by David C. Lindberg (Oxford: Clarendon Press, 1983).

Broecke, Lara, Cennino Cennini's Il libro dell'arte: A New English Translation and Commentary with Italian Transcription (London: Archetype Publications, 2015).

Dürer, Albrecht, Schriftlicher Nachlass, ed. by Hans Rupprich, 3 vols (Berlin: Deutscher Verlag für Kunstwissenschaft, 1969).

Kepler, Johannes, Gesammelte Werke, ed. by Max Caspar and Walter van Dyck, 23 vols (Munich: C. H. Beck, 1938).

Kepler, Johannes, Optics. Paralipomena to Witelo and \& Optical Part of Astronomy, trans. by William H. Donahue (Santa Fe: Green Lion Press, 2000).

Neri, Antonio, L'Arte vetraria distinta in libri sette (Florence: de' Gunti, 1612).

Porta, Giambattista della, Natural Magick by John Baptista Porta, a Neapolitane: in Twenty Books ... Wherein are Set Forth all the Riches and Delights of the Natural Sciences (London: Printed for Thomas Young and Samuel Speed, 1658).

\section{Secondary Works}

Belting, Hans, Florence and Baghdad: Renaissance Art and Arab Science, trans. by Deborah Lucas Schneider (Cambridge, Mass.: Belknap Press of Harvard University Press, 2011).

Bergdolt, Klaus, Der dritte Kommentar Lorenzo Ghibertis: Naturwissenschaften und Medizin in der Kunsttheorie der Frührenaissance (Weinheim: VCH, Acta Humaniora, 1988).

Blair, Ann, Too Much to Know: Managing Scholarly Information before the Modern Age (New Haven: Yale University Press, 2010).

Clagett, Marshall, Archimedes in the Middle Ages. Vol. 4: A Supplement on the Medieval Latin Traditions of Conic Sections (Philadelphia: The American Philosophical Society, 1980). 
Clarke, Mark, 'Writing Recipes for Non-Specialists, c. 1300: The Anglo-Latin "Secretum philosophorum", Glasgow MS Hunterian 110', in Sources and Serendipity: Testimonies of Artists' Practice, ed. by Erma Hermens and Joyce H. Townsend (London: Archetype Publications, 2009), pp. $50-64$.

Clark, Stuart, Vanities of the Eye: Vision in Early Modern European Culture (Oxford: Oxford University Press, 2007).

Crary, Jonathan, Techniques of the Observer: On Vision and Modernity in the Nineteenth Century (Cambridge, Mass.: The MIT Press, 1990).

Damm, Heiko, Michael Thimann and Claus Zittel, The Artist as Reader: On Education and NonEducation of Early Modern Artists (Leiden: Brill, 2012).

Dupré, Sven, 'Die Sichtbarkeit und Unsichtbarkeit von Körperwissen in der Kodifikation der Künste in der frühen Neuzeit', Paragrana: Internationale Zeitschrift für Historische Anthropologie, 25 (1) (2016), 110-29.

Dupré, Sven, 'Images in the Air: Optical Games, Magic, and Imagination', in Spirits Unseen: The Representation of Subtle Bodies in Early Modern European Culture, ed. by Christine Göttler and Wolfgang Neuber (Leiden: Brill, 2008), pp. 71-92.

Dupré, Sven, 'Kepler’s Optics without Hypotheses', Synthese, 185 (2012), 501-25.

Dupré, Sven, 'Mathematical Instruments and the "Theory of the Concave Spherical Mirror": Galileo's Optics beyond Art and Science', Nuncius, 15 (2) (2000), 551-88.

Dupré, Sven, 'Optics, Instruments and Painting, 1420-1720: Reflections on the Hockney-Falco Thesis', Special Issue of Early Science and Medicine, 10 (2) (2005), 125-339.

Dupré, Sven, 'Printing Practical Mathematics: Oronce Fine's "De speculo ustorio" between Paper and Craft', in The Worlds of Oronce Finé: Mathematics, Instruments and Print in Renaissance France, ed. by Alexander Marr (Donington: Shaun Tyas, 2009), pp. 64-82.

Dupré, Sven, 'The Historiography of Perspective and "Reflexy-Const" in Netherlandish Art', Nederlands Kunsthistorisch Jaarboek, 61 (2011), 35-60.

Dupré, Sven, 'The Value of Glass and the Translation of Artisanal Knowledge in Early Modern Antwerp', in Trading Values in Early Modern Antwerp, ed. by Bart Ramakers, Christine Göttler, and Joanna Woodall, Netherlands Yearbook for Art History, 64 (Leiden: Brill, 2014), pp. 138-61.

Dupré, Sven, 'Trading Luxury Glass, Picturing Collections and Consuming Objects of Knowledge in Early Seventeenth-Century Antwerp', Intellectual History Review, 20 (1) (2010), 53-78.

Dupré, Sven, and Christine Göttler, 'Hidden Artifices', in Knowledge and Discernment in the Early Modern Arts, ed. by Sven Dupré and Christine Göttler (New York: Routledge, 2017), pp. 1-16.

Dupré, Sven, and Michael Korey, 'Inside the Kunstkammer: The Circulation of Optical Knowledge and Instruments at the Dresden Court', Studies in History and Philosophy of Science, 40 (4) (2009), 405-20.

Dupré, Sven, Bert de Munck and Mark Clarke, Transmission of Artists' Knowledge (Brussels: Royal Flemish Academy of Arts and Sciences, 2012).

Eamon, William, Science and the Secrets of Nature: Books of Secrets in Medieval and Early Modern Culture (Princeton: Princeton University Press, 1994). 
Fiorentini, Erna, 'Subjective Objective. The Camera Lucida and Protomodern Observers', Bildwelten des Wissens: Kunsthistorisches Jahrbuch für Bildkritik, 2 (2004), 58-66.

Gage, John, Colour and Meaning: Art, Science and Symbolism (London: Thames \& Hudson, 1999).

Garber, Daniel, 'Merchants of Light and Mystery Men: Bacon's Last Projects in Natural History', Journal of Early Modern Studies, 3 (1) (2014), 91-106.

Goulding, Robert, 'Deceiving the Senses in the Thirteenth Century: Trickery and Illusion in the Secretum philosophorum', in Magic and the Classical Tradition, ed. by C. Burnett and W. F. Ryan (London: The Warburg Institute, 2006), pp. 135-62.

Hackenberg, Michael, 'Books in Artisan Homes of Sixteenth-Century Germany', Journal of Library History, 21 (1986), 72-91.

Hall, Bert S., 'Der Meister sol auch Kennen Schreiben und Lesen: Writings about Technology ca. 1400-ca. 1600 A.D. and their Cultural Implications', in Early Technologies, ed. by Denise SchmandtBesserat (Malibu: Undena Publications, 1979), pp. 47-58.

Heikamp, Detlef, Studien zur mediceischen Glaskunst: Archivalien, Entwurfszeichnungen, Gläser und Scherben (Florence: Kunsthistorisches Institut, 1986).

Hills, Paul, Venetian Colour: Marble, Mosaic, Painting and Glass 1250-1550 (New Haven: Yale University Press, 1999).

Hockney, David, Secret Knowledge: Rediscovering the Lost Techniques of the Old Masters (London: Thames \& Hudson, 2001).

Jalobeanu, Dana, and Cesare Pastorino, 'Introduction', in 'Instruments \& Arts of Inquiry: Natural History, Natural Magic and the Production of Knowledge in Early Modern Europe', Special Issue of Journal of Early Modern Studies, 3 (2014), 9-13.

James Elkins, James, The Poetics of Perspective (Ithaca: Cornell University Press, 1994).

Kern, Ulrike, 'The Art of Conservation I: Theodore de Mayerne, the King's Black Paintings and Seventeenth-Century Methods of Restoring and Conserving Paintings', The Burlington Magazine, 157 (2015), 700-708.

Krautheimer, Richard, and Trude Krautheimer-Hess, Lorenzo Ghiberti (Princeton: Princeton University Press, 1982).

Lautier, Claudine, and Dany Sandron, Antoine de Pise: L'art du vitrail vers 1400 (Paris, Comité des Travaux Historiques et Scientifiques, 2008).

Leong, Elaine, and Alisha Rankin (eds.), Secrets and Knowledge in Medicine and Science, 1500-1800 (Aldershot: Ashgate, 2011).

Lindberg, David C., Theories of Vision. From al-Kindi to Kepler (Chicago: University of Chicago Press, 1976).

Long, Pamela O., Openness, Secrecy, Authorship: Technical Arts and the Culture of Knowledge from Antiquity to the Renaissance (Baltimore: Johns Hopkins University Press, 2001).

Massey, Lyle, Picturing Space, Displacing Bodies: Anamorphosis in Early Modern Theories of Perspective (University Park, Pennsylvania: The Pennsylvania State University Press, 2007).

Panofsky, Erwin, Perspective as Symbolic Form, trans. by Christopher S. Wood (New York: Zone Books, 1997). 
Peiffer, Jeanne, 'Projections Embodied in Technical Drawings: Dürer and his Followers', in Picturing Machines 1400-1700, ed. by Wolfgang Lefèvre, (Cambridge, Mass.: The MIT Press, 2004), pp. 24575 .

Poulle, Emmanuel, Un constructeur d' instruments astronomiques au XVe siècle: Jean Fusoris (Paris: Librairie Honoré Champion, 1963).

Principe, Lawrence, The Secrets of Alchemy (Chicago: University of Chicago Press, 2013).

Raynaud, Dominique, L'hypothèse d'Oxford. Essai sur les origins de la perspective (Paris: Presses universitaires de France, 1998).

Rees, Joachim, Die verzeichnete Fremde: Formen und Funktionen des Zeichnens im Kontext europäischer Forschungsreisen 1770-1830 (Paderborn: Wilhelm Fink, 2015).

Roccasecca, Pietro, 'Gentile da Fabriano, A Miracle of Saint Nicholas: A Rigorous Nonperspective Spatial Representation', Center: Record of Activities and Research Reports, National Gallery of Art, Washington, 21 (2001), 126-30.

Roccasecca, Pietro, 'Not Albertian', Center: Record of Activities and Research Reports, National Gallery of Art, Washington, 22 (2002), 167-69.

Rose, Paul Lawrence, 'Jacomo Contarini (1536-1595), a Venetian Patron and Collector of Mathematical Instruments and Books', Physis, 18 (2) (1976), 117-30.

Rosińska, Grażyna, 'Optyka W XV wieku miedzy nauka sredniowieczna a nowozytna', Studia Copernicana, 24 (1986).

Sauer, Christine, 'Eine kunsttechnologische Handschrift aus dem Besitz Albrecht Dürers', in DürerForschungen (Nürnberg: Verlag des Germanischen Nationalmuseums, 2009), II, pp. 275-96.

Siegert, Bernhard, 'Kulturtechnik', in Einführung in die Kulturwissenschaft, ed. by Harun Maye and Leander Scholz (Munich: Wilhelm Fink Verlag, 2011), pp. 95-118.

Smith, A. Mark, 'Reflections on the Hockney-Falco Thesis: Optical Theory and Artistic Practice in the Fifteenth and Sixteenth Centuries', Early Science and Medicine, 10 (2) (2005), 163-86.

Smith, A. Mark, From Sight to Light: The Passage from Ancient to Modern Optics (Chicago: University of Chicago Press, 2014).

Trachtenberg, Marvin, Dominion of the Eye: Urbanism, Art and Power in Early Modern Florence (Cambridge: Cambridge University Press, 1997).

Trevor-Roper, H., Europe's Physician. The Various Life of Sir Theodore de Mayerne (New Haven: Yale University Press, 2006).

Vandamme, E., 'Een 16e-eeuws Zuidnederlands receptenboek', Jaarboek van het Koninklijk Museum voor Schone Kunsten (1974), 101-37. 